\title{
THE CORRELATION OF MOTHER'S AGE AT MARRIAGE AND MOTHER'S WORK STATUS WITH EXCLUSIVE BREASTFEEDING
}

\author{
Lina Juhaidah \\ Faculty of Public Health, Universitas Airlangga, 60115 Surabaya, East Java, Indonesia \\ Corresponding Author: Lina Juhaidah \\ Email: lina.juhaidah-2016@fkm.unair.ac.id
}

\begin{abstract}
The best nutrition for babies is breast milk. Breast milk should be given exclusively without any additions in the first six months. According to previous research, a woman's age at marriage will affect the practice of exclusive breastfeeding to their babies, as young mothers are often not ready to have and care for babies. The work status of mothers also has a large impact on exclusive breastfeeding practices. The goal of this study was to discover the correlation between age at marriage and the work status of mothers with exclusive breastfeeding practices. This research was an observational study with the subjects being 94 mothers of children aged 0-5 years in Ngringinrejo Village, Kalitidu District, Bojonegoro Regency from 3 July to 9 August, 2019. This study used data from the professional placement activity or Praktik Kerja Lapangan (PKL) conducted by the students of the public health study program of Airlangga University. The outcome of this research showed that there was no meaningful relationship between the age of marriage of mothers and practices of exclusive breastfeeding $(\mathrm{p}$-value $=0.973$ ) and there is also no statistical relationship between the work status of mothers and exclusive breastfeeding practices ( $\mathrm{p}$-value $=0.276$ ). However, it was discovered that mothers who gave exclusive breastfeeding were mostly not working, and mothers who did not breastfeed exclusively were mostly in employment. The conclusion of this research is the absence of a correlation between age at marriage and the work status of mothers with exclusive breastfeeding.
\end{abstract}

Keywords: exclusive breastfeeding, age at marriage, works

\begin{abstract}
ABSTRAK
Nutrisi paling baik untuk bayi adalah Air Susu Ibu (ASI). ASI sebaiknya diberikan secara eksklusif tanpa tambahan apapun pada enam bulan pertama. Menurut penelitian sebelumnya, perempuan yang menikah di usia muda akan mempengaruhi praktik pemberian ASI eksklusif kepada bayinya, hal ini dikarenakan ibu berusia muda sering kali belum siap untuk memiliki dan mengurus bayi. Status bekerja ibu juga memiliki dampak besar pada praktik menyusui eksklusif. Studi ini bertujuan untuk mengetahui hubungan antara usia menikah dan status bekerja ibu dengan praktik menyusui eksklusif. Penelitian ini merupakan studi observasional yang dikerjakan dengan subjek 94 ibu dari anak usia 0-5 tahun di Desa Ngringinrejo, Kecamatan Kalitidu, Kabupaten Bojonegoro pada tanggal 3 Juli sampai 9 Agustus 2019. Studi ini menggunakan data dari Praktik Kerja Lapangan (PKL) yang dilaksanakan oleh mahasiswa Program Studi Kesehatan Masyarakat, FKM Universitas Airlangga. Hasil studi memperlihatkan tidak ada hubungan bermakna antara usia ibu menikah dengan tindakan menyusui eksklusif (p-value= 0,973) dan juga tidak ada keterkaitan statistik pada status bekerja ibu dengan praktik menyusui eksklusif (p-value=0,276). Meski demikian, ditemukan hasil bahwa ibu yang menyusui secara eksklusif sebagian besar tidak bekerja, dan ibu yang tidak menyusui secara eksklusif sebagian besar adalah pekerja. Studi ini memiliki kesimpulan bahwa tidak ada keterkaitan antara usia ibu menikah dan status bekerja ibu dengan tindakan menyusui eksklusif.
\end{abstract}

Kata kunci: ASI eksklusif, usia menikah, pekerjaan

\section{INTRODUCTION}

Exclusive breastfeeding without any additives is recommended for at least the time from birth to 6 months of age. After passing the age of 6 months, it is permissible to give textured foods or drinks other than breast milk to babies. Exclusive breastfeeding is the second point stated in the clean and healthy living behavior list or Perilaku Hidup Bersih dan Sehat (PHBS). It is also the best source of nutrition and can prevent various diseases, including acute respiratory infections (ARIs), poisoning, and diarrhea in infants (Central Bureau of Statistics et al., 2018). 
Breast milk has nutrients that are important for a baby's growth and development. The process of exclusive breastfeeding can also build the relationship between the mother and the child to be closer. Exclusive breastfeeding can also erase the budget for buying formula milk. To support exclusive breastfeeding activities, the government always strives to educate the public to take exclusive breastfeeding actions (Bojonegoro Regency Health Office, 2019).

Although exclusive breastfeeding has many advantages, the practice of exclusive breastfeeding in Indonesia is still relatively low. The coverage of infants $<6$ months who received exclusive breastfeeding in 2017 was 52\%. The median exclusive breastfeeding given to children aged 0-3 years in 2017 in Indonesia is 3 months. Whereas $21 \%$ of infants aged $0-1$ months have consumed formula milk (Central Bureau of Statistics et al., 2018).

Bojonegoro Regency is located in the province of East Java. The results of exclusive breastfeeding coverage in East Java Province as obtained by the Indonesian Demographic and Health Survey (IDHS) 2017 stated that only $12.2 \%$ of children received exclusive breastfeeding. Most of the other babies are given other foods and drinks besides breast milk (Central Bureau of Statistics et al., 2020).

The coverage rate for exclusive breastfeeding in Bojonegoro Regency according to the 2018 Health Profile is quite high. The percentage of exclusive breastfeeding with infants 0-6 months in Bojonegoro Regency in 2018 reached $87.9 \%$. While the achievement rate of the Pungpungan Health Center whose work area includes Ngringinrejo Village in 2018 is $79 \%$. However, this figure could be higher than it is because if a baby aged 0 or 1 month and so on was only breastfed during the survey period, then he or she was recorded as a child aged 0-6 months who were exclusively breastfed (Bojonegoro Regency Health Office, 2019).

The mother's age at marriage can also affect the activity of exclusive breastfeeding to the baby. Studies conducted in several lower socio-economic areas of India has shown this. The results of the study concluded that the age of marriage in women affects the practice of exclusive breastfeeding (Nagaraja, Joseph, and Shashidhara, 2020).

Another study explains the relationship between women who marry and become mothers at a young age with non-exclusive breastfeeding.
The reception of information related to exclusive breastfeeding education is hindered by the background of young married mothers who are dominated by women with low levels of education. Many young mothers are also persuaded by advertisements and choose to give formula milk to their babies (Fau, Nasution, and Hadi, 2019).

Marriage at a young age that is not accompanied by a readiness to have children will have an impact on the women's pattern of parenting. Physical, mental, emotional, and psychosocial immaturity causes a person to tend to not to be ready to have children at a young age. This unpreparedness is also included in exclusive breastfeeding (Lumbantoruan, 2018).

The definition of adolescents according to the WHO is an age between 10-19 years, while the National Population and Family Planning Commission or Badan Kependudukan dan Keluarga Berencana Nasional (BKKBN) defines adolescents as unmarried people aged 10-24 years (Indonesian Ministry of Health, 2017). In Indonesia, the National Population and Family Planning Commission created a program to improve the quality of youths, one of which is to promote to the public that the ideal age for marriage for men is 25 and 21 for women (National Population and Family Planning Commission, 2017).

Women who marry at an early age are exposed to the risk of getting pregnant and giving birth to babies at an early age as well. The 2017 IDHS data shows that 7\% of women aged 15-19 years in Indonesia are already mothers. Meanwhile, $87.3 \%$ of women in the 2017 IDHS data are married but do not have children and want to have children soon (Central Bureau of Statistics et al., 2018). This data shows that most women want to have children immediately after marriage. However, having children in their teens would lead these mothers to be vulnerable to various health problems for both the mother and the child in the womb. Having children at a young age also reduces a mother's chances of continuing her education and career (Central Bureau of Statistics et al., 2018).

A mother's work status is another contributing factor besides the mother's age at marriage and affects the practice of exclusive breastfeeding. Actively working mothers often have a barrier to exclusive breastfeeding. This obstacle lies in the number of activities carried out outside the home and the shortness of 
maternity leave (Anggraeni, Nurdiati, and Padmawati, 2015).

Nevertheless, today's economic demands trigger women to work. The 2017 IDHS data states that $53 \%$ of women in the age range of 15 54 are workers. This percentage becomes higher if it is reduced to women who are married, which is $62 \%$. Meanwhile, if categorized by area of residence, women work in urban areas are as much as $55 \%$ and in rural areas are as much as 52\% (Central Bureau of Statistics et al., 2018).

This study aims to determine whether there is a relationship between age at marriage and the work status of mothers with exclusive breastfeeding practices. Previous studies have focused more on mothers who married at an early age, while this study compares mothers who got married at the age of $<20$ years and those aged 20 years and over. This research aims to determine whether there is a relationship between the age of married mothers and the status of work mothers with exclusive breastfeeding practices for infants in the Ngringinrejo Village, Kalitidu District, Bojonegoro Regency in 2019.

\section{METHOD}

This research is an analytic observational study with a cross-sectional study scheme. Both independent and dependent variables are measured at the same time. This study used data from the professional placement activity of the Airlangga University Public Health Study Program, located in Ngringinrejo Village. This village is located in Kalitidu District, Bojonegoro Regency. The data was collected from activities from 3 July to 9 August 2019. The ethics of the research data sources were reviewed to obtain a certificate number 1769-KEPK.

Mothers of toddlers who are registered at the Posyandu in Ngringinrejo Village are the subjects of this study. The research respondents are guardians who represent these toddlers. A simple random sampling technique was used to determine how large the sample will be. The number of samples obtained from the population of children under five in Ngringinrejo Village is 94 children.

A questionnaire was also conducted to complete the data collection effort through an interview method. Mother's age at marriage and mother's occupation are the independent variables studied in this study. The dependent variable studied is the act of exclusive breastfeeding of mothers to their children.
The dependent variable is divided into two, namely exclusive breastfeeding and not breastfeeding. The mothers' work status are grouped into yes and no. The variable of maternal age at marriage is divided into early marriage and sufficient age. Early age refers to the age of adolescents according to WHO, namely 10-19 years (WHO, 2014).

This study uses two stages of data processing, namely univariable and bivariable analysis. The univariable analysis will describe the frequency and percentage of each variable studied. Whereas the bivariable analysis with the chi-square test will check whether there is a relationship between maternal age at marriage and mother's employment status with exclusive breastfeeding.

\section{RESULT}

\section{Characteristics of Respondents}

The subjects of this study amounted to 94 people, as shown in Table 1. A total of $70.2 \%$ of respondents were married at the age of more than 19 years. Whereas the marriage age of $>30$ years is only owned by one respondent. Most respondents got married at the age range of 20-25 years.

Table 1. Characteristics of Respondents

\begin{tabular}{lcc}
\hline \multicolumn{1}{c}{ Characteristics } & $\mathbf{f}(\mathbf{n = 9 4 )}$ & $\mathbf{\%}$ \\
\hline $\begin{array}{l}\text { Age of Married Mother } \\
\text { Early marriage } \\
\text { (10-19 years) }\end{array}$ & 28 & 29.8 \\
$\begin{array}{l}\text { Married at sufficient age } \\
\text { (>19 years) }\end{array}$ & 66 & 70.2 \\
\hline Age of Married Mother & & \\
\hline 10-15 years & 3 & 3 \\
16-19 years old & 25 & 27 \\
20-25 years & 60 & 64 \\
26-30 years old & 5 & 5 \\
$>30$ years & 1 & 1 \\
\hline Working Mother Status & & \\
\hline Yes & 44 & 46.8 \\
No & 50 & 53.2 \\
\hline Exclusive Breastfeeding & & \\
\hline Yes & 76 & 80.9 \\
No & 18 & 19.1 \\
\hline
\end{tabular}

The respondents were categorized based on the characteristics of the mother's work status, i.e., working or not working. The option of not working or in other words being a housewife was the answer for $53.2 \%$ of respondents. As many as 
$46.8 \%$ of the other respondents are working mothers.

A significant difference in results was obtained from the variable of exclusive breastfeeding. A total of $80.9 \%$ of mothers admitted to giving exclusive breastfeeding to their children. The other $19.1 \%$ of respondents did not e xclusively breastfeed their children.

\section{Mother's Age at Marriage and Exclusive Breastfeeding}

The cross-tabulation between the mother's age at marriage and practice of exclusive breastfeeding is shown in Table 2 . Mothers who got married at an adequate age (>19 years) constitute the majority of both mothers who breastfeed their children exclusively or not.

The chi-square test conducted with the variables maternal age at marriage and exclusive breastfeeding obtained a p-value of 0.973 . The result of a p-value greater than 0.05 indicates that there is no statistical relationship. Thus, the results of statistical test specifies that maternal age at marriage with exclusive breastfeeding practices do not have a significant correlation.

\section{Mothers' Work Status and Exclusive Breastfeeding}

It can be seen in Table 3 that 43 out of 76 mothers who exclusively breastfeed their children are housewives (45.7\%). Meanwhile, 11 out of 18 mothers who did not exclusively breastfeed were workers $(11.7 \%)$. These results are shown in the graph in Figure 1.

The relationship between the status of working mothers and the practice of exclusive breastfeeding is shown in Table 3. The p-value obtained from the statistical test conducted using the Chi-Square test is 0.276 . As it is greater than the value of 0.05 , this suggests that there is no significant correlation on the mothers' work status with the practice of exclusive breastfeeding.

\section{DISCUSSION}

The majority of respondents in this study gave exclusive breastfeeding to their children $(80.9 \%)$. Research by Umami and Margawati (2018) also found that most of their subjects $(70.6 \%)$ performed exclusive breastfeeding. However, a study by Lumbantoruan (2018) has more respondents who do not exclusively breastfeed their children $(68.1 \%)$.

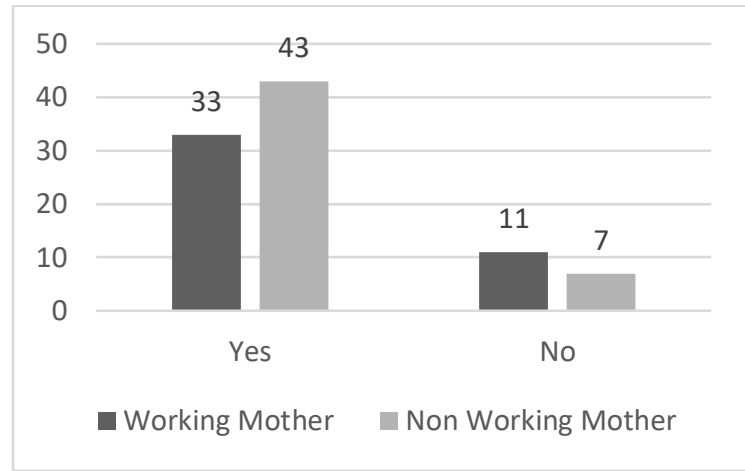

Figure 1. Percentage of Working Mother Status and Exclusive Breastfeeding.

The rate of exclusive breastfeeding in this study was slightly higher than the rate of exclusive breastfeeding at the Pungkungan Health Center $(79 \%)$, but lower than the percentage of exclusive breastfeeding in Bojonegoro Regency as a whole in 2018 (Bojonegoro Regency Health Office, 2019). This relatively high number may indicate an increase in all aspects that support exclusive breastfeeding in Bojonegoro Regency. However, this could also be due to the lack of understanding of the concept of exclusive breastfeeding by the data takers and research respondents.

According to WHO (2010), the act of breastfeeding infants aged $0-6$ months is classified into three types of breastfeeding, namely exclusive, predominant, and partial breastfeeding. Exclusive breastfeeding means that the baby does not consume anything other than breast milk, except for medical purposes. If there is a small amount of water or water-based drinks in addition to breast milk, it is called predominant breastfeeding. Whereas providing additional consumption for babies in addition to breast milk in the form of food and drinks will change the term exclusive breastfeeding to partial breastfeeding.

This study does not provide a clear division of the three breastfeeding patterns. Thus, there is a possibility that exclusive breastfeeding according to respondents is included in the category of dominant breastfeeding, or even partial breastfeeding. The 2017 IDHS shows that almost $60 \%$ of infants that are $<6$ months old are predominantly breastfed (Central Bureau of Statistics et al., 2018). 
Table 2. Relationship between Mother's Age at Married and Exclusive Breastfeeding

\begin{tabular}{|c|c|c|c|c|}
\hline \multirow[b]{2}{*}{ Age of Married Mother } & \multicolumn{2}{|c|}{ Exclusive Breastfeeding } & \multirow{2}{*}{$\begin{array}{c}\text { Total } \\
(\mathrm{N}=94) \\
(\mathrm{F}=\mathbf{1 0 0 \%})\end{array}$} & \multirow[b]{2}{*}{$p$-value } \\
\hline & $\begin{array}{c}\text { Yes } \\
(\mathrm{N}=76) \\
(\mathrm{F}=\mathbf{8 0 . 9 \%})\end{array}$ & $\begin{array}{c}\text { No } \\
(\mathrm{N}=18) \\
(\mathrm{F}=\mathbf{1 9 . 1 \%})\end{array}$ & & \\
\hline Early marriage (10-19 years) & $\begin{array}{c}22 \\
(23.4 \%)\end{array}$ & $\begin{array}{c}6 \\
(22.3 \%)\end{array}$ & $\begin{array}{c}28 \\
(29.8 \%)\end{array}$ & \\
\hline Married at sufficient age ( $>19$ years) & $\begin{array}{c}54 \\
(57.4 \%)\end{array}$ & $\begin{array}{c}12 \\
(12.8 \%)\end{array}$ & $\begin{array}{c}66 \\
(70.2 \%)\end{array}$ & 0.973 \\
\hline
\end{tabular}

Table 3. Relationship between Mother's Work Status and Exclusive Breastfeeding

\begin{tabular}{lcccc}
\hline \multirow{2}{*}{ Mother's Work Status } & \multicolumn{2}{c}{ Exclusive Breastfeeding } & Total & \\
\cline { 2 - 3 } & $\begin{array}{c}\text { Yes } \\
(\mathbf{n = 7 6}) \\
(\mathbf{F = 8 0 . 9 \% )}\end{array}$ & $\begin{array}{c}\mathbf{N o} \\
(\mathbf{n = 1 8}) \\
(\mathbf{F = 1 9 . 1 \% )}\end{array}$ & $\begin{array}{c}(\mathbf{n = 9 4 )} \\
(\mathbf{F = 1 0 0 \% )}\end{array}$ & p-value \\
\hline Work & 33 & 11 & 44 & \\
& $(35.1 \%)$ & $(11.7 \%)$ & $(46.8 \%)$ & 0.276 \\
Does not work & 43 & 7 & 50 & \\
& $(45.7 \%)$ & $(7.4 \%)$ & $(53.2 \%)$ & \\
\hline
\end{tabular}

Nevertheless, the definition of exclusive breastfeeding was given to the respondent at the time of data collection, so the high rate of exclusive breastfeeding was based on the respondent's answers.

This study does not provide a clear division of the three breastfeeding patterns. Thus, there is a possibility that exclusive breastfeeding according to respondents is included in the category of dominant breastfeeding, or even partial breastfeeding. The 2017 IDHS shows that almost $60 \%$ of infants that are $<6$ months old are predominantly breastfed (Central Bureau of Statistics et al., 2018). Nevertheless, the definition of exclusive breastfeeding was given to the respondent at the time of data collection, so the high rate of exclusive breastfeeding was based on the respondent's answers.

\section{Mothers' Age at Marriage}

The majority of respondents in this study $(70.2 \%)$ were married at an adequate age (>19 years). The other $29.8 \%$ of respondents were married at the age of 19 years. Studies have shown that women have a vulnerability to marry at a young age compared to men (Central Bureau of Statistics et al., 2020).

Moreover, women living in rural areas are vulnerable to early marriage. Indriyati and Handayani (2018) found that women living in urban areas tend to have a higher age at first marriage than women living in rural areas. The median age of first marriage/Umur Kawin Pertama (UKP) for women living in rural areas is 20.9 years and women living in urban areas have a median rate of 2 years higher, which is 22.9 years (Central Bureau of Statistics et al., 2018).

According to the 2017 IDHS, the age at first marriage for women increases with the increase in the last level of education that the woman received. Economic conditions can also affect a women's age at first marriage. Women in the lowest wealth quintile have a median UKP of 20.6 years, while those in the top wealth quintile are 23.8 years (Central Bureau of Statistics et al., 2018).

The percentage of women aged 15-19 years who already have children is also higher for women living in rural areas that is $10 \%$ to 5\%. The 2017 IDHS also stated that women aged 15-19 years that have had children are mostly women with their latest education being elementary school (Central Bureau of Statistics et al., 2018). As this research was conducted in a rural area, this may be the reason for the high rate of early marriage in this study.

Furthermore, the high rate of marriage at an early age among women is supported by the weak regulation of marriage limits in Indonesia. The Child Protection Act does not allow marriage under the age of 18 . However, the Marriage Law in Indonesia legalizes 16- 
year-old women and 19-year-old men to get married. This regulation did not change at all until the data collection for this study took place. Changes in the minimum age for marriage to 19 years for women have just been ratified in Marriage Law no. 16 of 2019. Therefore, National Population and Family Planning Commission held a Marriage Age Maturation program for 25 year old men and 21 year old women (National Population and Family Planning Commission, 2017).

The absence of a significant correlation between maternal age at marriage and exclusive breastfeeding is the conclusion of the chi-square test results in this study. Similar results were also presented by research by Musmar and Qanadeelu (2012). Their study found that there was no significant difference between the ages of 15 to 20 and 21 to 30 years of marriage with exclusive breastfeeding activities.

However, the same study obtained different results for respondents with the age of marriage equal to or more than 30 years. There is a significant relationship in women who are married at the age of 30 years and over with the possibility not to exclusively breastfeed their children ( $\mathrm{p}$-value $=0.00001)$ and prefer formula milk as a source of nutrition for their babies. The explanation of the results of this study is the amount of social support provided by large families to young mothers. For example, parents in Palestine still feel responsible for their daughter's in early adulthood (aged 15-29 years). Parents in Palestine also uphold the culture of exclusive breastfeeding.

Conversely, research conducted in India (2020) found that the age of marriage for women was a statistically related factor (pvalue $=<0.001)$ with the practice of exclusive breastfeeding. This study used data from the Annual Health Survey (AHS) which covers about $50 \%$ of India's population from a lower social and economic standing. This study concluded that marriages held under the legal age can reduce the proportion of exclusive breastfeeding (Nagaraja, Joseph, and Shashidhara, 2020). This is because mothers who marry and become pregnant at a young age have not yet matured physically, mentally, emotionally, and psychosocially. This condition will affect the mother's preparation to become a parent, including in terms of breastfeeding her child (Lumbantoruan, 2018).
The results of the 2012 IDHS data research conducted by Indriyati and Handayani (2018) obtained different results. This study suggested that the mother's age at first marriage harms the act of exclusive breastfeeding. In this study, women who got married at an older age have a lower probability of exclusively breastfeeding their child. The results of the analysis of this study proves that the higher the women's education level, the higher the age of their first marriage. The low levels of exclusive breastfeeding in women with high marriage age occurs because marriages carried out at an older age with higher education will cause women to have higher capital as well, so that the costs of exclusive breastfeeding activities will be greater. Women with higher education who marry at an older age tend to choose to work so they do not have time to exclusively breastfeed their children and require more facilities if they want to breastfeed exclusively, such as the need for pumps and refrigerators at work to store breast milk. This can also occur due to a high level of education but not followed by good knowledge about exclusive breastfeeding.

A qualitative study involving young mothers also found that married at a young age partially breastfeed. Unwanted pregnancy is the reason most respondents get married at a young age. Thus, it can be concluded that they are not ready to marry, have a household, and take care of children. Unpreparedness to have children can also be seen from non-exclusive breastfeeding (Sholichah et al., 2017).

Further discussion of the low rate of exclusive breastfeeding in unwanted pregnancies is evidenced in studies Keddem et al. (2018). This study explains that the mother's intention to become pregnant and have children will affect the length of time the mother breastfeeds. Babies born from pregnancies that are not wanted by the mother will get breast milk in a shorter time than babies born from pregnancies that are wanted by the mother. The father's intention to have children also influences in making decisions about breastfeeding mothers to babies. This is because fathers are more likely to be present and have a greater influence on the mother's behavior such as providing support for early initiation of breastfeeding / Inisiasi Menyusui Dini (IMD) and exclusive breastfeeding if the 
child's pregnancy has been expected/intended beforehand.

Based on the explanation above, the results of this study show that age at marriage does not have a direct relationship with exclusive breastfeeding because there are many more influential things such as readiness and planning in marriage and child care, family and partner support, and mother's knowledge regarding exclusive breastfeeding.

\section{Mother's Work Status}

The majority of this study's respondents are mothers who do not work. Research by Bahriyah, Jaelani, and Putri (2017) also found that $75.7 \%$ of their 152 respondents are not working. Widdefrita and Mohanis (2014) also found that mothers who do not work are the majority of their research respondents $(67.3 \%)$.

The absence of a significant relationship from this study's statistical tests on the mothers's work status and exclusive breastfeeding practices has also been found in several previous studies. Umami and Margawati (2018) have conducted a study that showed that there was no relationship between a mother's work status and the practice of exclusive breastfeeding ( $\mathrm{p}$-value $=0.394)$. Moreover, Erfiyani and Nuria (2020) also found similar results, where there mother's work status does not correlate with the practice of exclusive breastfeeding ( $\mathrm{p}$-value $=0.958)$.

Conversely, the existence of a relationship between the mother's work status and the act of exclusive breastfeeding were obtained from research by Widdefrita and Mohanis (2014) and Bahriyah, Jaelani, and Putri (2017) who argued that mothers with the unemployed status have a greater opportunity to exclusively breastfeed their children. The amount of time spent outside the home without bringing the baby is an obstacle for exclusive breastfeeding for working mothers.

According to Widdefrita and Mohanis (2014), the relationship between work status and exclusive breastfeeding is due to the short time limit during maternity leave. Working mothers prefer formula milk that could meet the nutritional needs of the baby when the mother is outside the home. In addition, the lack of knowledge about lactation management and facilities for pumping and storing breast milk in the work environment also hinders working mothers from being able to exclusively breastfeed their children in the first 6 months.

Research by Indriyati and Handayani (2018) also obtained a different finding, namely that working mothers had a higher probability of exclusive breastfeeding than non-working mothers. This is because the community of work mothers can share information and support each other related exclusive breastfeeding activities. Working mothers also find it easier to access information and have the means to support exclusive breastfeeding.

Employment can be generally divided into two sectors, formal and informal. Formal work is a business that is assisted by employees in the process. As many as $63.54 \%$ of Indonesian women who work in 2018 were in the informal employment sector. This figure will be different if it is associated with the area of residence. Of the female population living in rural areas, $74.68 \%$ work in the informal sector, while in urban areas this figure is lower at $45.46 \%$ (Central Bureau of Statistics et al., 2020). Therefore, mother's type of work can also affect the mother's exclusive breastfeeding practice to her child.

Moreover, the problem of short maternity leave and strict regulations regarding breastfeeding in the workplace will be experienced by mothers who work in the formal field. However, this issue can be overcome if the mother has a strong will to continue breastfeeding her baby. The existence of a refrigerator can also help mothers to provide breast milk by giving the milk to the baby when the mother isn't at home (Erfiyani and Nuria, 2020).

Informal jobs will have more flexible rules regarding leave and breastfeeding for babies. Mothers who work in the informal sector are usually able to stop working for some time after giving birth and start working when the baby is deemed old enough to be left at home or taken to work (Anggraeni, Nurdiati and Padmawati, 2015). Thus, the status of mothers who work both formally and informally cannot be used as a justification for ignoring exclusive breastfeeding.

Ngringinrejo village can be categorized as a rural area, therefore most working mothers are working in the informal sector and can take their babies to work or wait for their babies to 
be 6 months old before returning to work. In addition, the willingness to exclusively breastfeed also plays an important role in the act of exclusive breastfeeding for both working and non-working mothers. People living in rural areas also have more limited access to information than urban communities, including information on exclusive breastfeeding (Central Bureau of Statistics et al., 2018). These reasons may explain the absence of a significant relationship between the variables of maternal working status and exclusive breastfeeding in this study.

\section{CONCLUSIONS AND SUGGESTIONS}

\section{Conclusions}

The majority of mothers of toddlers in Ngringinrejo Village $(80.9 \%)$ exclusively breastfeed their children. We found that there is no statistical relationship between the age of the mother and the practice of exclusive breastfeeding. There is a tendency for working mothers to not exclusively breastfeed, but statistically, these two variables are not related.

\section{Suggestions}

The health service facilities in Ngringinrejo Village is suggested to intensify the promotion and education related to exclusive breastfeeding since pregnancy. Training on pumping and storing breast milk is also necessary for working mothers.

\section{REFERENCES}

Anggraeni, I.A., Nurdiati, D.S. dan Padmawati, R.S., 2015. Keberhasilan ibu bekerja memberikan ASI eksklusif. Jurnal Gizi dan Dietetik Indonesia, 3(2), pp. 6976.

Bahriyah, F., Jaelani, AK and Putri, M., 2017. The Relationship of Mother's Employment to Exclusive Breastfeeding for Babies in the Work Area of the Sipayung Health Center. Journal of Endurance, 2(2), pp. 113118.

Bojonegoro Regency Health Office, 2019. Profil Kesehatan Kabupaten Bojonegoro 2018. Bojonegoro: Bojonegoro Regency Health Office.

Central Bureau of Statistics, National Population and Family Planning Commission, Indonesian Ministry of
Health and USAID, 2018. Survei Demografi dan Kesehatan Indonesia 2017. Jakarta: BKKBN.

Central Bureau of Statistics, National, National Development Planning Agency, UNICEF and Center for Research and Advocacy on the Protection and Quality of Life of Children, University of Indonesia, 2020. Pencegahan Perkawinan Anak: Percepatan yang Tidak Bisa Ditunda. PUSKAPA.

Erfiyani, R.I. dan Nuria, 2020. Faktor yang Berhubungan dengan Perilaku Pemberian ASI Eksklusif di Kelurahan Pegirian Kecamatan Semampir Kota Surabaya. Medical Technology and Public Health Journal, 4(1), hal.91100.

Fau, S.Y., Nasution, Z. dan Hadi, A.J., 2019. Faktor Predisposisi Ibu Usia Remaja terhadap Pemberian ASI Eksklusif pada Bayi di Kecamatan Luahagundre Maniamolo Kabupaten Nias Selatan. Media Publikasi Promosi Kesehatan Indonesia, 2(3), hal.165-173.

Indonesian Ministry of Health, 2017. Information on Infodatin Situasi Kesehatan Reproduksi Remaja. Jakarta: Data and Information Center.

Indriyati dan Handayani, D., 2018. Teen Marriage and Feeding Behaviour to Children in Indonesia. Malaysian Journal of Economic Studies, 55(2), hal.151-166.

Keddem, S., Frasso, R., Dichter, M. dan Hanlon, A., 2018. The Association between Pregnancy Intention and Breastfeeding. Journal of Human Lactation, 34(1), hal.97-105.

Lumbantoruan, M., 2018. Hubungan Karakteristik Ibu Menyusui dengan Pemberian ASI Eksklusif pada Bayi di Desa Bangun Rejo Dusun 1 Kecamatan Tanjung Morawa Tahun 2018. Jurnal Maternal dan Neonatal, 3(1), hal.13-22.

Musmar, S.G. dan Qanadeelu, S., 2012. Breastfeeding Patterns among Palestinian Infants in The First 6 Months in Nablus Refugee Camps: A Cross-Sectional Study. Journal of Human Lactation, 28(2), hal.196-202.

Nagaraja, R., Joseph, M. dan Shashidhara, S., 2020. Factors Influencing Exclusive 
Breastfeeding (EBF) in Empowered Action Group (EAG) States and Assam. Clinical Epidemiology and Global Health, 8(1), hal.170-174.

National Population and Family Planning Commission, 2017. Usia Pernikahan Ideal 21-25 Tahun. [online] Available at: 〈https://www.bkkbn.go.id>.

Sholichah, F., Fatimah-Muis, S., Margawati, A. dan Khan, A., 2017. Early Marriage and Unsuccessful Exclusive Breastfeeding among Semarang district of Indonesian Teenage Mothers. Man in India, 97(19), hal.213-228.

Umami, W. dan Margawati, A., 2018. Faktorfaktor yang Mempengaruhi Pemberian ASI Eksklusif. Jurnal Kedokteran
Diponegoro, 7(4), hal.1720-1730.

WHO, 2010. Indicators for Assessing Infant and Young Child Feeding Practices. WHO Press.

WHO, 2014. World Health Organization Health for The World's Youth A Second Chance in The Second Decade. World Health Organization. Geneva, Switzerland.

Widdefrita dan Mohanis, 2014. Peran Petugas Kesehatan dan Status Pekerjaan Ibu dengan Pemberian ASI Ekslusif. Jurnal Kesehatan Masyarakat Andalas, 8(1), hal.40-45. 